\title{
第46巻 第10号訂正のお知らせ
}

ERRATA FOR THE VOL. 46, NO. 10 ISSUE

Vol. 46, No. 10,433 (1990)

\section{全芳香族，肪脂族および脂環族ポリアミドの 吸着水の凍結・融解挙動}

\author{
日本女子大学 家政学部 被服学科 許斐 毅志・山本 之子 \\ FREEZING AND MELTING BEHABIORS OF WHOLLY AROMATIC, \\ ALIPHATIC AND ALICYCLIC POLYAMIDES \\ 訂 正 \\ FREEZING AND MELTING BEHAVIOR OF WATER ABSORBED \\ ON WHOLLY AROMATIC, ALIPHATIC AND ALICYCLIC POLYAMIDES
}

内外の全䋐維・全加工段階のデータ・資料を収録

\section{1年版『繊維ハンドブック』}

(「化絨ハンドブック」改題)

〈B 6 判 400頁 5,000円(消費税別, 送料込み)〉

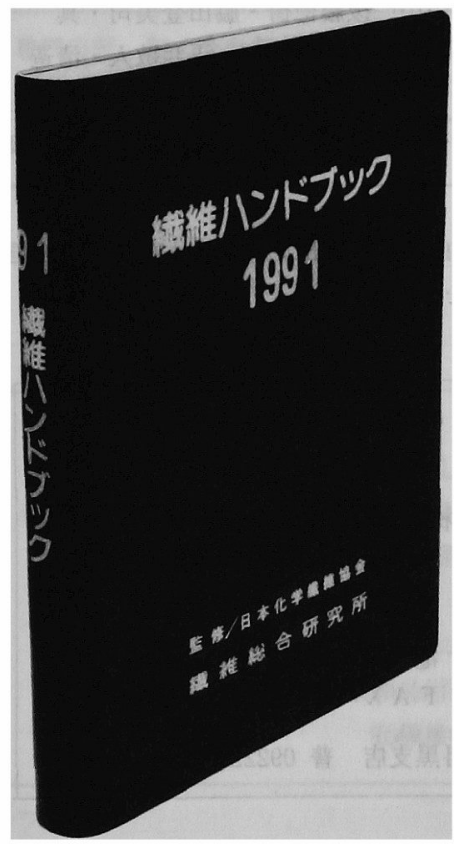

日本と世界の最新の繊維データバンクとして定評のある『䋐維ハン ドブック」(監修/日本化学織維協会, 発行/緎維総合研究所)の「1991 年版」が,このほど発刊された。

1959年の初版から数えると, 27 回目の刊行に当り, 毎回, 細部にわ たる見直しと增補が行われてきた(この間，「1987年版」より，それま での「化緁ハンドブック」を「織維ハンドブック」と改題)。織維原 料から素材, テキスタイル, アパレル, 流通, 消費に至るまでの全織 維, 全加工段階の最新のデー夕・資料が系統立てて収録されており, 文字どおり“䄉維のことなら何でも分る”ハンドブックとなってい る。

構成は「国内統計編」「国際統計編」「資料編」の 3 部から成り, 全 体を通じて既刊内容との継続性に細かい配虑が払われている。

「織維ハンドブック」に衣替えして 4 回目の本書は, 繊維業界に携 っている人にはもちろん, 緁維を研究, あるいは䄉維に関心を持って いる人にとっても活用範囲は誠に広い。

お問合せ・お申込みは, 繊維総合研究所まで

東 京/ 103 東京都中央区日本橋本町 3-1-11(繊維会館 6 階) TEL 03-3241-1573

大阪/ 541 大阪市中央区瓦町 4-6-8(大阪化学䄉維会館 7 階) TEL 06-231-2871 